\title{
The influence of Brazilian soils properties in Americium sorption
}

\author{
M.A.V. Wasserman ${ }^{1, *}$, T.R. Pereira ${ }^{1}$, E.R.R. Rochedo ${ }^{1}$, W.O. Sousa ${ }^{1}$, \\ D.V. Pérez ${ }^{2, *}$, E.F.M. Pinheiro ${ }^{3, *}$ and F.F.L. Simões Filho ${ }^{4}$ \\ ${ }^{1}$ Instituto de Radioproteção e Dosimetria; 22780-160 Rio de Janeiro, RJ, Brasil \\ e-mail: angelica@ird.gov.br \\ ${ }^{2}$ Centro Nacional de Pesquisa de Solos/EMBRAPA. R. Jardim Botânico, 1024, \\ CEP 22460-000, RJ, Brasil \\ ${ }^{3}$ Universidade Federal Rural do Rio de Janeiro, Instituto de Agronomia, Seropédica, \\ $R J$, Brasil \\ ${ }^{4}$ Instituto de Engenharia Nuclear, Rua Hélio de Almeida, 75, Cidade Universitária, \\ Ilha do Fundão, 21941-972, Rio de Janeiro, RJ, Brasil \\ ${ }^{*} \mathrm{CNPq}$ researchers
}

\begin{abstract}
Although some radioecological studies have been accomplished in Brazilian soils supplying useful information to optimization of emergency planning actions in rural areas and to the management of soils contaminated by ${ }^{137} \mathrm{Cs},{ }^{60} \mathrm{Co}$ and ${ }^{90} \mathrm{Sr}$, few studies were made with transuranic elements in tropical agricultural areas. The different scenarios found in Brazilian agricultural environments enhance the importance of studying the biogeochemical behavior of radionuclides in representative soils. The objective of this work was to determine the mobility of ${ }^{241} \mathrm{Am}$ in 3 different Brazilian agricultural soils evaluating migration with depth and $\mathrm{Kd}$ values for ${ }^{241} \mathrm{Am}$ and the effect of organic amendments on this behavior. A strong effect of organic amendments on mobility of americium could be observed. The values of $\mathrm{Kd}$ obtained in all studied tropical soils were however smaller than those found in European soils and from those recommended by IAEA to be used as default values in the absence of regional data. This result reinforces the vulnerability of some tropical soils to a contamination, emphasizing the need to use of regional values.
\end{abstract}

\section{INTRODUCTION}

Many studies radioecological concerning transport and the distribution of radionuclides in soil have been developed in Europe after the Chernobyl accident e.g. [1-6] improving the understanding on the behavior of radionuclides in agricultural ecosystems in the long term. Although the soil can act as physical and geochemical barrier for the retention of deposited radionuclides, changes in its physicalchemical conditions due to agricultural practices, land use, or simply natural edapho-climatic evolution, can modify the fate of the radionuclides, favoring their desorption and release to the soil solution or changing their geochemical partitioning. Once released into soil solution, radionuclides can be available for root uptake or for migration to deeper layers into soils profiles. In soils of temperate climate with high soil organic matter content, large mobility of the radionuclides was observed, turning them available for root uptake for a longer period when compared with the strong retention made by clay minerals [1]. Deposited radionuclides on soils are generally fixed by adsorption on reactive sites on clay mineral soil particles, or by ion exchange and precipitation as hydroxide or sulfide, but also by complex formation with organic compounds [7]. Several studies recognize that among parameters affecting the behavior of the radionuclides, organic substances are very important in determining the fate of radionuclides in soil/plant system. It is known that, due to the high acidities and relatively low molecular weights of fulvic acids, metal ions associated with fulvic acids are more soluble than those with humic acids [8]. 
Transuranic elements and fission products are relevant nuclides in the context of waste management. Although some radioecological studies have been accomplished in Brazilian soils supplying useful information to optimization of emergency planning actions in rural areas and to the management of soils mainly contaminated by ${ }^{137} \mathrm{Cs},{ }^{60} \mathrm{Co}$ and ${ }^{90} \mathrm{Sr}$ e.g. [9-11], few studies were made with transuranic elements in tropical agricultural areas. The objective of this work was to investigate the effects of organic substances on the mobility of ${ }^{241} \mathrm{Am}$ in tropical soils.

For that the chemical fractionation of organic substances in soil and the coefficient of distribution were determined in soils that received organic amendment before be artificially contaminated with ${ }^{241} \mathrm{Am}$ and remained undisturbed for at least 5 years.

\section{METHODS}

The experimental work was developed at the Experimental Area and at Radioecology Laboratory of IRD - Institute of Radiological Protection and Dosimetry. The field experiment was performed in pots of $0.25 \mathrm{~m}^{2}$ and $50 \mathrm{~cm}$ of deep. About $40 \mathrm{~cm}$ of the soil was the added to the pots, isolated from the drainage material by a plastic lattice. A Ferralsol, a Nitisol and a Histosol were selected to perform this study. Ferralsol are the most representative soils of Brazil, occupying $38.7 \%$ of the total area of the country and distribute it throughout the national territory.

To evaluate the role of organic amendment in Nitisol and Ferralsol, two pots were maintained without amendment addition, two other pots received a recommended dose of organic amendment for radish $\left(2 \mathrm{~kg} \cdot \mathrm{m}^{-2}\right)$ and 2 pots received the double of recommended dose of organic amendment for radish $\left(4 \mathrm{~kg} . \mathrm{m}^{-2}\right)$. Two other pots were filled with a Histosol, as a soil control due to the natural high organic matter content. After the organic amendment, the soils were spiked with a solution containing ${ }^{241} \mathrm{Am}$, spraying it directly in the soil surface. Each pot received about $640 \mathrm{~Bq}$ of ${ }^{241} \mathrm{Am}$. The organic amendment used in this experiment was obtained in the Unit of Compost of the Organic Material of Pinheiral (RJ, Brazil), where the compost is made up from the leaves swept from the streets of the Pinheiral city. This experimental result was obtained five years after the organic amendment in order to investigate the effect of its aging on Am sorption.

The distribution coefficient $\mathrm{Kd}$ is an important factor defining the sorption ability of soil. This factor is defined as a ratio between radionuclide equilibrium concentrations in solid phase and pore solution of soil. The higher Kd corresponds to the higher sorption ability of soils with respect to radionuclides and their lower concentration in pore solution.

The methodology for Kd determination followed the procedure described at Roussel-Debet [12]. The sorption experiments were carried out using the batch technique: $10 \mathrm{~g}$ of soil samples was mixed in a $200 \mathrm{ml}$ polypropylene centrifuge with $80 \mathrm{~mL}$ of a solution having $\sim 515 \mathrm{~Bq} . \mathrm{L}^{-1}$ of americium in nitric acid were shacked at room temperature for 72 hours. The solid-liquid phases were separated by centrifuging at a speed of $1200 \mathrm{rpm}$ for $1 \mathrm{~h}$. Then, $40 \mathrm{ml}$ was taken from the solution and its activity was measured in a HPGe detector.

The chemical fractionation of organic substances in soil was performed according to the methodology proposed by Swift (1996) modified by Benites et al. [13] in order to quantify the humic fractions in simplified and easy method. Humic acids have low solubility under acidic conditions normally found in tropical soils. These compounds are responsible for most of the CEC of the organic layers surface soils. Fulvic acids are the humic compounds that present higher solubility due to their larger polarity and smaller molecular size. These compounds are the main mechanisms responsible for transport of cations in the soil through organo-metallic complexes, which characterizes the process of lixiviation of chetates [14]. The humin consists of an agglomerate of humic and non-humic materials, presenting low reactivity, but, in most tropical soils, represent the largest part of the humified soil carbon.

The samples of soil were analyzed by gamma spectrometry, following standard procedures of the Environmental Analysis Laboratory of IRD. Pedological analyses were performed by EMBRAPA according to their Standard routine analytical procedures [15]. 
Table 1. Physico-chemical Properties of Ferralsol, Nitisol and Histosol.

\begin{tabular}{|c|c|c|c|}
\hline Parameters & Ferralsol & Nitisol & Histosol \\
\hline $\mathrm{P}\left(\mathrm{mg} \mathrm{kg}^{-1}\right)$ & 1 & 12 & 16 \\
\hline $\mathrm{K}^{+}\left(\mathrm{cmol} \mathrm{kg}^{-1}\right)$ & 0.03 & 0.04 & 0.19 \\
\hline $\mathrm{Ca}^{+2}\left(\mathrm{cmol} \mathrm{kg}^{-1}\right)$ & 1.5 & 1.4 & 0.5 \\
\hline $\mathrm{Mg}^{+2}\left(\mathrm{cmol} \mathrm{kg}^{-1}\right)$ & 0.3 & 0.7 & nd \\
\hline $\mathrm{Al}^{3+}\left(\mathrm{cmol} \mathrm{kg}^{-1}\right)$ & 1.6 & 3 & 9.3 \\
\hline $\mathrm{H}^{+}\left(\mathrm{cmol} \mathrm{kg}^{-1}\right)$ & 3.5 & 5.4 & 26.2 \\
\hline $\mathrm{pH}(\mathrm{KCl})$ & 3.7 & 3.7 & 3.4 \\
\hline $\mathrm{OM}(\%)$ & 3.8 & 4.7 & 22.7 \\
\hline $\mathrm{Fe}_{2} \mathrm{O}_{3}\left(\mathrm{~g} \mathrm{~kg}^{-1}\right)$ & 49 & 155 & 41 \\
\hline $\mathrm{MnO}\left(\mathrm{g} \mathrm{kg}^{-1}\right)$ & 0.08 & 0.34 & 0.08 \\
\hline CEC $\left(\mathrm{cmol} \mathrm{kg}^{-1}\right)$ & 5.9 & 10.6 & 37.4 \\
\hline${ }^{241} \mathrm{Am}\left(\mathrm{Bq} \mathrm{Kg}^{-1} \mathrm{~d} . \mathrm{w} \pm \mathrm{sd}\right)$ & $204 \pm 17$ & $149 \pm 19$ & $259 \pm 32$ \\
\hline Texture & clay & clay & clay \\
\hline Mineralogy & kaolinite & kaolinite & kaolinite \\
\hline
\end{tabular}

nd $=$ non detectable.

\section{RESULTS AND DISCUSSION}

The main physico-chemical properties of soils are described in Table 1 . In this table is possible to observe that all soils are acidic and clay-textured, but they differ in regard to nutrient content $(\mathrm{Ca}, \mathrm{K}, \mathrm{P}$ and $\mathrm{Mg}$ ), organic matter (OM) content, Fe oxides, Mn oxides and the cationic exchange capacity (CEC), i.e., properties that can affect the sorption mechanisms of radionuclides in soil [9]. On the Histosol, the high content of organic matter leads to the high CEC soil, showing the high sorption power of soil, although, as can be seen, the complex is saturated mainly with $\mathrm{H}^{+}$and $\mathrm{Al}^{+3}$, rather than with essential nutrients $\left(\mathrm{Ca}^{+2}, \mathrm{Mg}^{+2}\right.$ and $\left.\mathrm{K}^{+}\right)$, which compromises the productivity of the soil.

Figure 1 shows the vertical migration of ${ }^{241} \mathrm{Am}$ in studied soils (controls). These results show that ${ }^{241}$ Am remains concentrate in the superficial layers of Ferralsol and Nitisol without organic amendment, when compared with concentration found in deeper layers. These results partially agree with Sokolik [5] that found that $90 \%$ of Am was located in the superficial layers $(0-5 \mathrm{~cm})$ in dry meadow soils from Belarus after Chernobyl accident. However, results obtained for the Histosol, the soil with a natural high content of organic matter, showed a profile less sharp as those from Ferralsol and Nitisol suggesting an increase of mobility for Americium do deeper layers.

Figure 2 show the profile of concentration of ${ }^{241} \mathrm{Am}$ in Ferralsol after organic amendment (2 and $4 \mathrm{~kg} \cdot \mathrm{m}^{-2}$, respectively). In this figure we can observe a significant migration of ${ }^{241} \mathrm{Am}$ in Ferralsol after organic amendment. This behavior is much more marked in the Ferralsol that received the higher dose of amendment $\left(4 \mathrm{~kg} . \mathrm{m}^{-2}\right)$. The profile of ${ }^{241} \mathrm{Am}$ in Nitisol after organic amendment, presented Figure 3 , shows a significant migration of ${ }^{241} \mathrm{Am}$ to deeper layers after fertilization with higher dose of amendment $\left(4 \mathrm{~kg} \cdot \mathrm{m}^{-2}\right)$, with the important lost in the superficial layer. According to these results it is suggested that the organic amendment, usual agricultural practice in Brazilian soils, may increase ${ }^{241}$ Am migration.

The figure 4 presents the contents of soil organic carbon in studied soils. These results shows that after organic amendment, only the double dose was effective to increase organic carbon contents in these soils, but it is still lower than natural contents found in Histosol. This figure also shows that with the aging of organic amendment, the soils amended returned to its original organic carbon content and the Histosol presented a reduction in its original content, indicating an important degradation of labile compounds of soil organic matter.

Table 2 presents the values of $\mathrm{Kd}$ for ${ }^{241} \mathrm{Am}$ found in the studied soils and $\mathrm{Kd}$ values reported by Roussel-Debet [12]. The difference between the values determined in this study and those found 

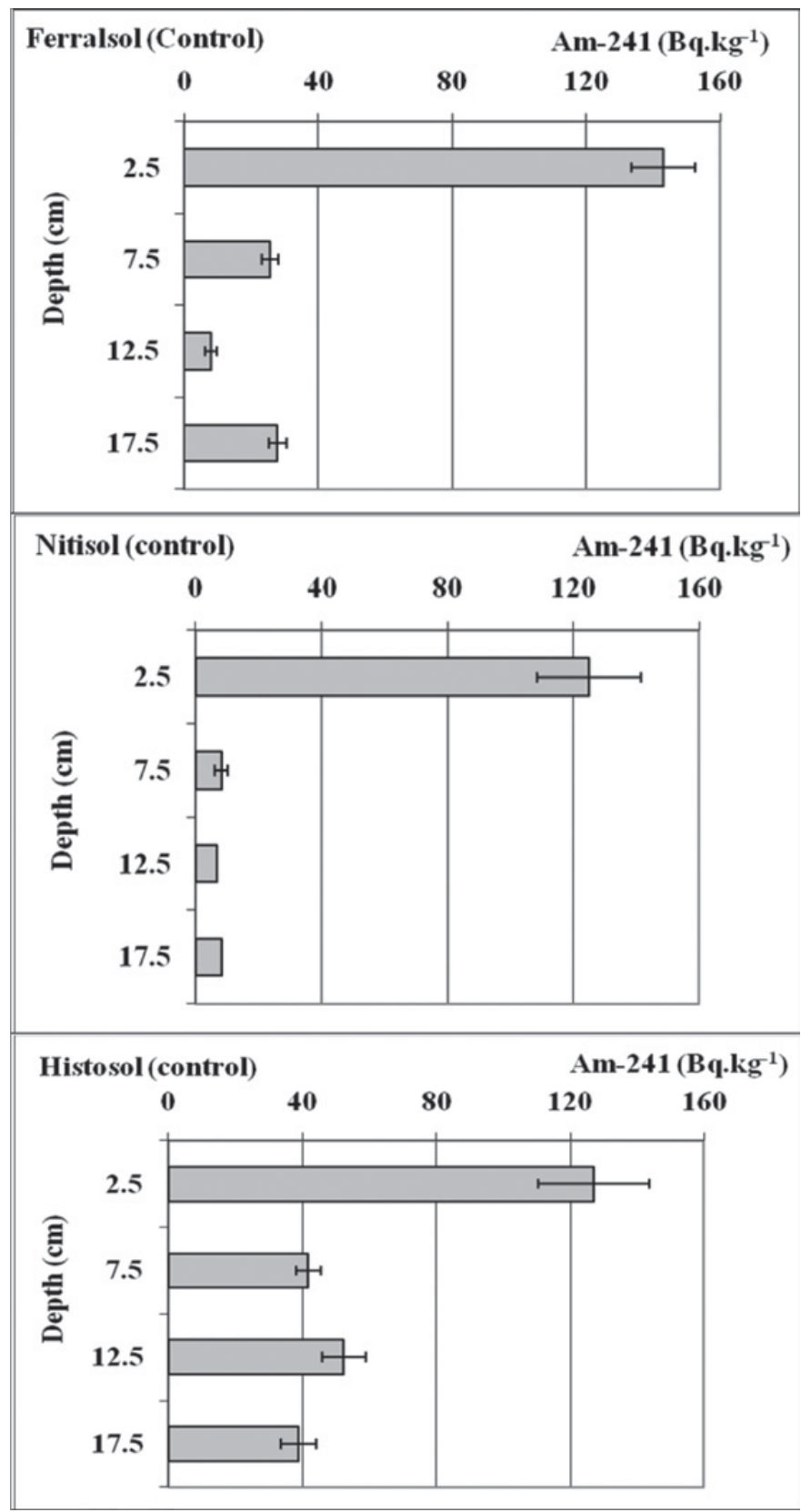

Figure 1. ${ }^{241}$ Am profile in Ferralsol and Nitisol without organic amendment and Histosol.

in soils of temperate climate areas seems to confirm the great mobility of americium in the tropical soils and, therefore, this aspect must be considered when establishing protective measures after an accidental contamination. As the aging of organic amendment was enough to make disappear the differences between organic treatments the $\mathrm{Kd}$ values for amended soil were similar to soils without amend, evidenced by very low variation.

Complexation of actinides with organic matter may have two opposites effects. If complexed by organic matter, their migration will be reduced. On the other hand, if the stable complexes are formed 


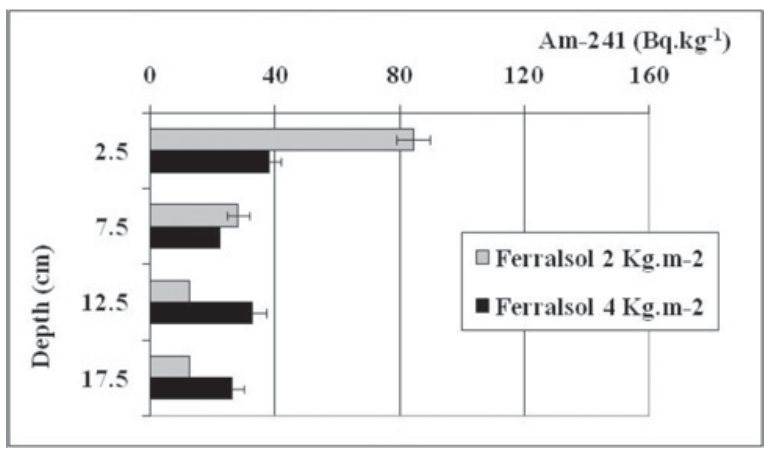

Figure 2. ${ }^{241}$ Am migration in Ferralsol with $2 \mathrm{~kg} \mathrm{~m}^{-2}$ and $4 \mathrm{~kg} \mathrm{~m}^{-2}$ of organic amendment.

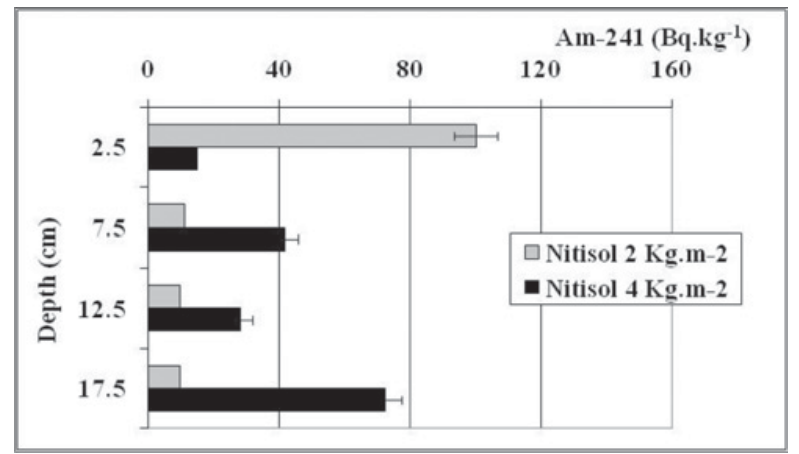

Figure 3. ${ }^{241} \mathrm{Am}$ migration in Nitisol with $2 \mathrm{~kg} \mathrm{~m}^{-2}$ and $4 \mathrm{~kg} \mathrm{~m}^{-2}$ of organic amendment.

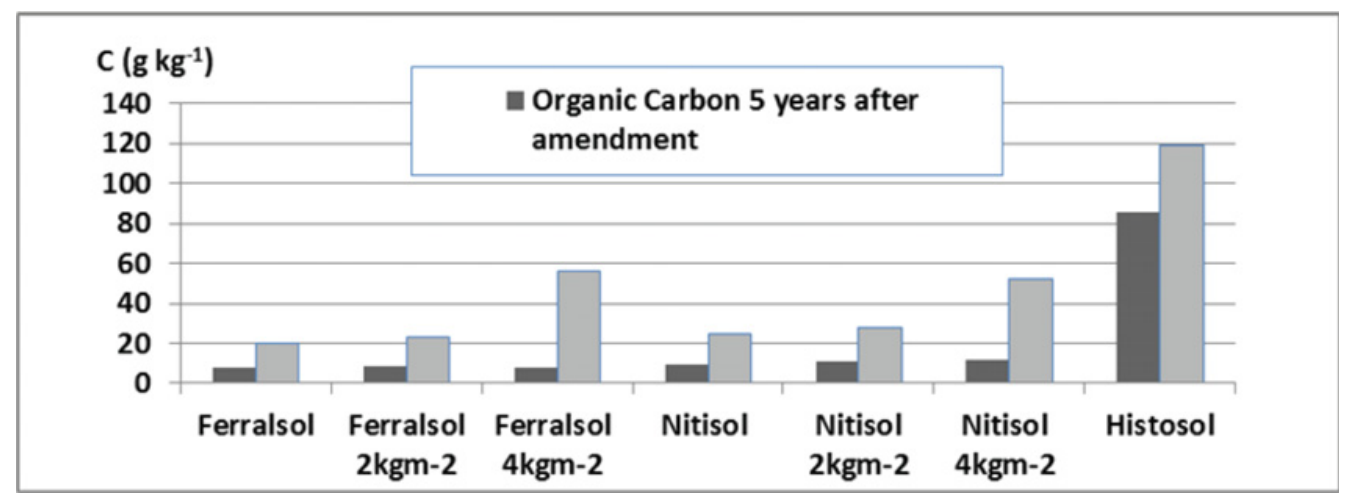

Figure 4. Organic carbon content in soils.

with the organic matter soluble, transport of radionuclides can be increased [16]. Table 3 shows the correlation coefficients between the values of chemical fractionation of organic matter with the values of $\mathrm{Kd}$. According to this table we can see that the $\mathrm{Kd}$ has a good correlation with organic carbon, humin and humic acids, indicating that these fraction are the main responsible for retention of americium., so the mobility observed for Am with the organic amendment can be associated to the soluble fraction, the fulvic acids. 
Table 2. Values of $\mathrm{Kd}$ for ${ }^{241} \mathrm{Am}\left(\mathrm{L} \mathrm{kg}^{-1}\right)$ found in French soil and in this study.

\begin{tabular}{llllllll}
\hline Fluvisol & Andosol & Cambisol & Calcisol & Histosol & Nitisol & Ferralsol & Reference \\
\hline $67 \pm 5$ & $411 \pm 28$ & $988 \pm 28$ & $4103 \pm 1140$ & & & & {$[12]$} \\
\hline & & & $56(n=2)_{-}$ & $47 \pm 1(n=3)$ & $44 \pm 1(\mathrm{n}=3)$ & This study \\
\hline
\end{tabular}

Table 3. Correlation coefficients for chemical fractionation with $\mathrm{Kd}$ values.

\begin{tabular}{lcccc}
\hline & Fulvic acids & Humic acids & Humin & Organic Carbon \\
\hline $\mathrm{r}^{2}$ & 0.662 & $0.943^{*}$ & $0.933^{*}$ & $0.942^{*}$ \\
\hline${ }^{*} 99.9 \%$ significant $)$ & & &
\end{tabular}

\section{CONCLUSIONS}

In this study we could observe that the organic amendment plays an important role in the fate of deposited americium in the soil surface, influencing, in this case, its migration to deeper layers into soil profile. Tropical soils that did not receive any organic amendment presented a higher retention of ${ }^{241} \mathrm{Am}$ in the surface, unlike those receiving organic amendments, presented a wider distribution of the radionuclide along the soil profile. This work also determined values of distribution coefficient (Kd), which did not was done before for tropical soils. The Kd values obtained were lower than those found in European soils, confirming the higher mobility for ${ }^{241} \mathrm{Am}$ in tropical soil. Since the values of Kd are widely used as a basis for assessing environmental risk, the adoption of regional values, minimizes errors in estimates of risk assessment. This result advertise about the vulnerability of tropical soils contaminated by ${ }^{241} \mathrm{Am}$ once low Kd implies low retention factor of the components of soil and increases the possibility for plant uptake (not evaluated in this study) or to migrate to deeper layers in the soil (as effectively observed). The application of organic amendment can change the mechanism of sorption in soils with low cationic exchange capacity. In the case of ${ }^{241} \mathrm{Am}$ the absence of the correlation observed between $\mathrm{Kd}$ and soluble organic matter confirm the mobility of Am in the soil-plant system enhanced by fulvic acids.

\section{References}

[1] Salbu, B.; Oughton, D.H.; Ratnikov, A.V. et al., The Mobility of 137Cs and 90Sr in Agricultural Soils in The Ukraine, Belarus, and Russia, Health Physics, 67, p. 518-528 (1994)

[2] Barci-Funel, G.; Dalmasso, J.; Barci, V. L.; Ardisson, G. Study of the transfer of radionuclides in trees at a forest site, Sci. Tot. Environ. 173/174, p.369-373 (1995)

[3] Colle, C. \& Roussel-Debet, S. Sols et végétaux, In Le Césium137: de l'environnement à 1'Homme. Institute de Protection et de Sûreté Nucléaire, EDP Sciences, $1^{a}$ Ed., 63-92 (2000)

[4] Mcgee, E. J., Synnott, H. J.; Johanson, K. J., Fawaris, B. H.; Nielsen, S. P.; Horrill, A.D.; Kennedy, V. H.;Barbayianis, N.; Veresoglou, D. S.; Dawson, D. E. Colgan, P. A. \& Mcgarry, A. T., Chernobyl fallout in a Swedish spruce forest ecosystem. J. Environ. Radioactivity 48: p. 59-78 (2000)

[5] Sokolik, G. A., Ivanova. T.G., Leinova, S.L., Ovsiannikova, S.V. \& Kimlenko, I.M., Migration ability of radionuclides in soil-vegetation cover of Belarus after Chernobyl accident. Environment International 26. p. 183-187 (2001)

[6] Herranz, M., Legarda, F.; Elejalde, C., Romero, F., Distribution of fallout Cs-137 in soils from Biscay. Radiation Physics and Chemistry 61, p. 683-684 (2001)

[7] Lee, M.H. \& Lee, C.W. Association of fallout-derived Cs 137, Sr 90, Pu 239,240 with a natural organic substances in soils. Journal of Environmental Radioactivity 47. p 253-262 (2000).

[8] Stevenson, F.J., Humus chemistry: Genesis, composition, reactions. 2 end. John Wiley and Sons, Inc., New York, NY (1994) 
[9] Wasserman, M.A., Perez, D.V., Bartoly, F., Biogeochemical behavior of 137Cs 60Co in tropical and soils. In: Bréchignac F. (Ed.), The Radioecology e Ecotoxicology of Terrestrial and Estuarine Environments. Radioprotection - Colloques, 37-C1, p.277-282 (2002)

[10] Wasserman, M.A.V.; Bartoly, F.; Portilho, A.P.; Rochedo, E.R.R; Viana, A.G.; Perez, D.V.; Conti, C.C., The effect of organic amendment on potential mobility and bioavailability of ${ }^{137} \mathrm{Cs}$ and ${ }^{60} \mathrm{Co}$ in tropical soils. J. Environmental Radioactivity, 99, p. 554-562 (2008)

[11] Portilho, A.P. A Influência da Adição de Composto Orgânico na Mobilidade e Biodisponibilidade do 137Cs e do 60Co em Solos Tropicais. MSc dissertation, Instituto de Radioproteção e Dosimetria. 79p. (2005)

[12] Roussel-Debet, S., Experimental values for $241 \mathrm{Am}$ and $239+240 \mathrm{Pu} \mathrm{Kd}$ 's in French agricultural soils. Journal of Environmental Radioactivity, 79, p. 171-185 (2005)

[13] Benites, V.M.; Madari, B.; Machado P.L.O.A. Extração e Fracionamento Quantitativo de Substâncias Húmicas do Solo: Um procedimento simplificado de baixo custo. Rio de Janeiro. Embrapa Solos, Comunicado Técnico 16 (2003)

[14] Duchaufour, P. Pedology: Pedogenesis and Classification. George Allen and Unwin, London. 448 $\mathrm{p}(1982)$

[15] EMBRAPA. Manual de Métodos de Análise de Solo, 2 ed, EMBRAPA - CNPS (2007)

[16] Maes, N.; Beauwens, T.; Wang, L.; Moors, H.; De Cannière, P.; Delécaut, G.; Put, M.; Dierckx, A.; Gens, R.; Warwick, P.; Hall, A.; Van Der Lee, J. And Maes, A. The Role of Natural Organic Matter in Radionuclide transport: The Migration Behaviour of 241Am - Organic Matter Complexes in Bloom Clay. In: Clays In Natural And Engineered Barriers For Radioactive Waste Confinement. International Meeting, December 9-12, Reims, France: p. 65-66 ((2002) 